\title{
Selective Enhancement of Tonic GABAergic Inhibition in Murine Hippocampal Neurons by Low Concentrations of the Volatile Anesthetic Isoflurane
}

\author{
Valerie B. Caraiscos, ${ }^{1}$ J. Glen Newell, ${ }^{3}$ Kong E. You-Ten, ${ }^{2}$ Erin M. Elliott, ${ }^{1}$ Thomas W. Rosahl, ${ }^{5}$ Keith A. Wafford, \\ John F. MacDonald, ${ }^{3,4}$ and Beverley A. Orser ${ }^{1,2,3,6}$ \\ ${ }^{1}$ Institute of Medical Science, Departments of ${ }^{2}$ Anesthesia, ${ }^{3}$ Physiology, and ${ }^{4}$ Pharmaceutical Sciences, University of Toronto, Toronto, Ontario M5S 1A8, \\ Canada, ${ }^{5}$ Merck Sharp and Dohme Research Laboratories, Neuroscience Research Center, Terlings Park, Harlow, Essex CM20 2QR, United Kingdom, and \\ ${ }^{6}$ Department of Anesthesia, Sunnybrook and Women's College Health Sciences Centre, Toronto, Ontario M4N 3M5, Canada
}

\begin{abstract}
Volatile (inhaled) anesthetics cause amnesia at concentrations well below those that cause loss of consciousness and immobility; however, the underlying neuronal mechanisms are unknown. Although many anesthetics increase inhibitory GABAergic synaptic transmission, this effect occurs only at high concentrations $(>100 \mu \mathrm{M})$. Molecular targets for low concentrations of inhaled anesthetics have not been identified. Here, we report that a tonic inhibitory conductance in hippocampal pyramidal neurons generated by $\alpha 5$ subunitcontaining $\mathrm{GABA}_{\mathrm{A}}$ receptors is highly sensitive to low concentrations of the volatile anesthetic isoflurane (ISO) (25 and $\left.83.3 \mu \mathrm{M}\right)$. The $\alpha 5$ subunit is necessary for enhancement of the tonic current by these low concentrations of isoflurane because potentiation is absent in neurons from $\alpha 5^{-l-}$ mice. Furthermore, ISO $(25 \mu \mathrm{M})$ potentiated recombinant human $\alpha 5 \beta 3 \gamma 2 \mathrm{~L}$ GABA receptors, whereas this effect was not seen with $\alpha 1 \beta 3 \gamma 2 \mathrm{~L} \mathrm{GABA}_{\mathrm{A}}$ receptors. These studies suggest that an increased tonic inhibition in the hippocampus may contribute to amnestic properties of volatile anesthetics.
\end{abstract}

Key words: amnesia; anesthesia; GABA; extrasynaptic; $\alpha 5$ subunit; heterologous expression

\section{Introduction}

The general anesthetic state is characterized by multiple desirable endpoints, including amnesia, analgesia, sedation, and immobility in response to pain (Campagna et al., 2003). Since the classical description of the "Stages of Ether Anesthesia," it has been recognized that different concentrations of anesthetics produce distinct behavioral effects (Gillespie, 1943). Memory is particularly sensitive to general anesthetics because amnesia occurs at concentrations well below those that cause sedation and immobility (Cook et al., 1978; Veselis et al., 2001; Pain et al., 2002). Commonly used inhaled anesthetics cause amnesia at concentrations fourfold lower than those required for immobility (Dwyer et al., 1992; Kandel et al., 1996; Dutton et al., 2001). The GABA subtype A receptor $\left(G_{A B A} R\right)$ is thought to be a primary target for most anesthetics, and the concentrations of halogenated anesthetics that potentiate $\mathrm{GABA}_{\mathrm{A}}$ Rs correlate with their abilities to induce general anesthesia (Mihic et al., 1994; Campagna et al., 2003). However, $\mathrm{GABA}_{\mathrm{A}}$ Rs that are sensitive to low concentrations of volatile anesthetics that cause amnesia have yet to be identified.

Received May 27, 2004; revised Aug. 9, 2004; accepted Aug. 10, 2004.

This research was supported by grants from the Canadian Institutes of Health Research (V.B.C., J.G.N., J.F.M., and B.A.O), a Career Scientist Award (B.A.O.), and the Canadian Anesthesiologists' Society (K.E.Y.-T.). We thank Lidia Brandes and Elzbieta Czerwinska for technical support.

Correspondence should be addressed to Dr. Beverley A. Orser, Department of Physiology, Room 3318, Medical Sciences Building, 1 King's College Circle, Toronto, Ontario M5S 1A8, Canada. Email: beverley.orser@utoronto.ca. D01:10.1523/JNEUROSCI.2063-04.2004

Copyright $\odot 2004$ Society for Neuroscience $\quad 0270-6474 / 04 / 248454-05 \$ 15.00 / 0$
$\mathrm{GABA}_{\mathrm{A}} \mathrm{Rs}$ are pentameric anion-selective ion channels that assemble from different classes of subunits $(\alpha 1-6, \beta 1-3, \gamma 1-3, \delta$, $\pi, \theta, \epsilon)$ (McKernan and Whiting, 1996). The subunit composition of $\mathrm{GABA}_{\mathrm{A}}$ Rs determines their pharmacological and biophysical properties as well as subcellular distribution patterns (Belelli et al., 1999). $\mathrm{GABA}_{\mathrm{A}}$ Rs regulate the transfer of information at inhibitory synapses by generating transient IPSCs. Recently, $\mathrm{GABA}_{\mathrm{A}}$ Rs have also been shown to generate a tonic form of inhibition through activation by low ambient concentrations of GABA (Bai et al., 2001; Semyanov et al., 2004). In CA1 pyramidal neurons, the tonic inhibitory conductance is generated by $\alpha 5$ subunit-containing $\mathrm{GABA}_{\mathrm{A}} \mathrm{Rs}\left(\alpha 5 \mathrm{GABA}_{\mathrm{A}} \mathrm{Rs}\right)$ (Caraiscos et al., 2004). Because the sensitivity of $\mathrm{GABA}_{\mathrm{A}}$ Rs to volatile anesthetics is influenced by the $\alpha$ isoform (Jenkins et al., 2001; Korpi et al., 2002), we tested the hypothesis that $\alpha 5 \mathrm{GABA}_{\mathrm{A}} \mathrm{Rs}$ that generate a tonic current in hippocampal pyramidal neurons are highly sensitive to low concentrations of the prototypic volatile anesthetic isoflurane (ISO). The results provide the first evidence of native $\mathrm{GABA}_{\mathrm{A}} \mathrm{Rs}$ in hippocampal neurons that are sensitive to subanesthetic concentrations of ISO $(25 \mu \mathrm{M})$. We also show that the $\alpha 5$ subunit is necessary for conferring sensitivity of pyramidal neurons to ISO $(25 \mu \mathrm{M})$, using neurons from $\alpha 5^{-/-}$mice.

\section{Materials and Methods}

Cell cultures and whole-cell recording. Experiments were approved by the Animal Care Committee of the University of Toronto. Primary cultures of hippocampal and cortical neurons were prepared as described previously (MacDonald et al., 1989) from $\alpha 5^{-l-}$ mice and wild-type (WT) 
$\alpha 5^{+/+}$littermates on postnatal day 1 . The $\alpha 5^{-/-}$mice were generated in a mixed 50\% C57BL/6 and 50\% 129SvEv genetic background, as described previously (Collinson et al., 2002). Given the limited availability of $\alpha 5^{+/-}$breeding pairs, neuronal cultures were also prepared from Swiss White mice and were used to determine the threshold concentration of isoflurane that modulated the tonic and synaptic currents. All other experiments that involved neurons were performed using WT and $\alpha 5^{-1-}$ mice. The tonic current is readily detected in cultured hippocampal neurons not treated with pharmacological agents intended to increase the ambient concentration of GABA (Bai et al., 2001; Yeung et al., 2003). However, to increase the amplitude of the tonic current and facilitate its characterization, cultures were treated with the GABA transaminase inhibitor vigabatrin $(100 \mu \mathrm{M})$ for $24 \mathrm{hr}$ before recording (Wu et al., 2003).

The extracellular solution contained (in $\mathrm{mm}$ ): $140 \mathrm{NaCl}, 1.3 \mathrm{CaCl}_{2}, 5.4$ $\mathrm{KCl}, 25$ HEPES, and 28 glucose, $\mathrm{pH}$ 7.4. Tetrodotoxin (300 nM) was added to block $\mathrm{Na}^{+}$channels, and 6-cyano-7-nitro-quinoxaline-2,3dione $(10 \mu \mathrm{M})$ and 2-amino-4-phosphonovaleric acid $(40 \mu \mathrm{M})$ were added to inhibit ionotropic glutamate receptors. Neurons were perfused using a computer-controlled multibarreled perfusion system with an exchange time of $\sim 3 \mathrm{msec}$ (SF-77B; Warner Instruments, Hamden, CT). Whole-cell currents were recorded under voltage-clamp $(-60 \mathrm{mV})$ conditions using an Axopatch 200 amplifier (Axon Instruments, Union City, CA) that was interfaced to a Digidata 1200 (InstruTech, Elmont, NY). To monitor series resistance, a hyperpolarizing voltage step of $10 \mathrm{mV}$ was applied. Only cells that demonstrated a stable access resistance were used for data analysis. Patch electrodes were filled with a solution containing (in mM): $140 \mathrm{CsCl}, 10 \mathrm{HEPES}, 11$ EGTA, $2 \mathrm{MgCl}_{2}, 1 \mathrm{CaCl}_{2}, 4 \mathrm{MgATP}$, and 2 tetraethylammonium, $\mathrm{pH}$ 7.3. Experiments were performed at room temperature.

ISO solutions were prepared and applied as described previously (Joo et al., 2001). The concentrations of ISO in samples obtained at the end of the perfusion barrels were measured previously using gas chromatography (Mihic et al., 1994; Joo et al., 2001). The highest concentration of ISO in the undiluted aqueous solution was $2500 \mu \mathrm{M}$. The potency of volatile anesthetics is most often described as the minimum alveolar concentration (MAC) that prevents movement in response to a noxious stimulus in $50 \%$ of subjects (Eger et al., 1965). The MAC equivalent for ISO in mice was calculated using a formula that adjusted the in vivo MAC value to room temperature (Joo et al., 2001). The aqueous-phase concentration of ISO equivalent to MAC for in vitro studies at room temperature is 253-280 $\mu \mathrm{M}$ (Franks and Lieb, 1993, 1998).

Heterologous expression. Human embryonic kidney (HEK) 293 cells were transiently transfected with cDNAs encoding human $\mathrm{GABA}_{\mathrm{A}} \mathrm{R} \alpha 5$ or $\alpha 1, \beta 3$, and $\gamma 2 \mathrm{~L}$ subunit isoforms (1:1:1 ratio) using Lipofectamine 2000 (Invitrogen, Carlsbad, CA). All cDNAs were subcloned into the mammalian expression vectors pCDM8 or pcDNA3.1(+) for heterologous expression. HEK 293 cells were incubated for $24-48 \mathrm{hr}$ before investigation. GABA-evoked currents were activated by applying GABA for $2 \mathrm{sec}$. ISO was preapplied for at least $30 \mathrm{sec}$ before coapplication with GABA.

Data analysis and statistics. The amplitude of the tonic current and total charge transfer $(Q)$ were measured as described previously (Wall and Usowicz, 1997; Bai et al., 2001). Drug efficacy was reported as percentage of control, where control equaled the amplitude of the tonic current revealed by bicuculline (BIC). Minimal tonic current was detected in $\alpha 5^{-1-}$ neurons (Caraiscos et al., 2004), so the ISO effects were reported as the change in $I_{\text {hold }}$. All results are reported as the mean \pm SEM. Statistical significance was determined using a Kruskal-Wallis or one-way ANOVA followed by an appropriate post hoc test.

\section{Results}

\section{Isoflurane selectively enhances tonic conductance}

Hippocampal pyramidal neurons generated a persistent tonic inhibitory conductance and transient postsynaptic currents, as shown in Figure $1 A$. The $\mathrm{GABA}_{\mathrm{A}} \mathrm{R}$ antagonist BIC $(100 \mu \mathrm{M})$ inhibited miniature IPSCs (mIPSCs) and reduced the tonic current by $32.9 \pm 5.6 \mathrm{pA}(n=19)$ (Fig. $1 A)$. ISO caused a concentration-
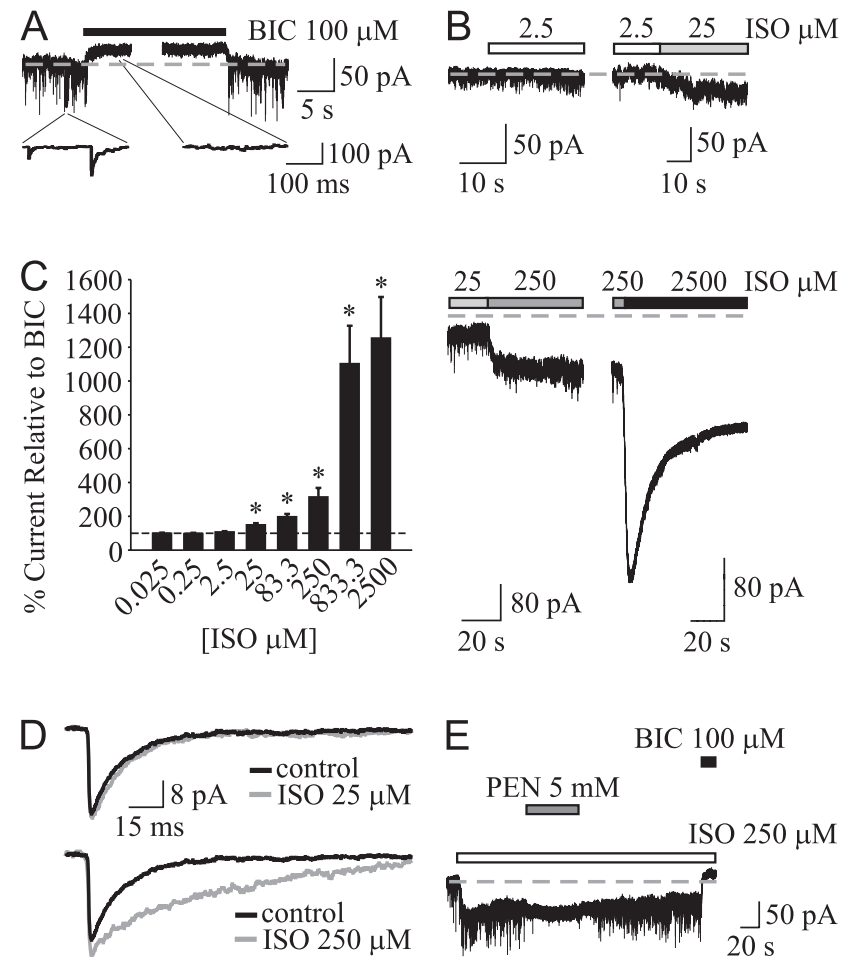

Figure 1. Effects of ISO on tonic and synaptic conductances in hippocampal neurons from Swiss White mice. $A$, Current recorded before and during the application of BIC (100 $\mu \mathrm{m})$. The dashed line depicts the baseline current before drug application. BIC revealed a tonic current as evidenced by an outward shift in the baseline current and blocked the transient inward mIPSCs. The bottom traces are temporal expansions of segments showing abolishment of mIPSCs by BIC. $B$, ISO potentiated the tonic current in a concentration-dependent manner. $C$, The bar graph illustrates the percentage change in peak tonic current by ISO. The dashed line indicates $100 \%$ $\left({ }^{*} p<0.05\right)$.D, Averaged mIPSC from a single neuron show that $250 \mu \mathrm{m}$ but not 25 or $83.3 \mu \mathrm{m}$ ISO (data not shown) prolonged the decay. E, PEN inhibited mIPSCs but not ISO (250 $\mu \mathrm{m})$ enhanced tonic current. BIC (100 $\mu \mathrm{M})$ inhibited the ISO-enhanced current.

dependent increase in the tonic current, as evidenced by an inward shift in the baseline. Low (sub-MAC) concentrations of ISO (25 and $83.3 \mu \mathrm{M}$ ) selectively enhanced the tonic current to 149 and $197 \%$ of control, respectively, but failed to alter mIPSCs $(p<0.05)$ (Fig. 1, Table 1). ISO $(250 \mu \mathrm{M})$ also increased the tonic current to $314 \%$ of control and caused a threefold increase in the duration of mIPSCs but reduced the frequency by 65\% (Fig. $1 B, C$; Table 1 ). The differential ISO sensitivity of the tonic and synaptic conductances to ISO was further illustrated by comparing net charge transfer. ISO $(25 \mu \mathrm{M})$ caused a 37 -fold greater increase in charge transfer for the tonic current compared with time-averaged synaptic currents $\left(Q_{\text {tonic }} 33.7 \pm 10.3 \mathrm{pC}, n=7\right.$ vs $Q_{\text {synaptic }} 0.4 \pm 0.9$, $n=6 ; p<0.05)$. The relative increase in charge transfer was even greater for ISO $(250 \mu \mathrm{M})$. Despite prolonging the time course of synaptic currents, ISO $(250 \mu \mathrm{M})$ failed to increase synaptic charge transfer because the frequency of mIPSCs was reduced $\left(Q_{\text {tonic }}\right.$ $117.1 \pm 31.3 \mathrm{pC}, n=7$ vs $\left.Q_{\text {synaptic }}-1.2 \pm 0.8 \mathrm{pC}, n=5 ; p<0.05\right)$.

To ensure that ISO $(250 \mu \mathrm{M})$ generated an inward current by targeting tonic but not synaptic receptors, penicillin (PEN) (5 $\mathrm{mM}$ ) and ISO were coapplied because PEN selectively inhibits mIPSCs (Yeung et al., 2003). PEN inhibited mIPSCs but failed to reduce the ISO-enhanced tonic current, whereas BIC reversibly inhibited the ISO-enhanced tonic current (Fig. 1E).

A 10-fold higher (clinically irrelevant) concentration of ISO $(2500 \mu \mathrm{M})$ activated a large inward current and also completely inhibited the synaptic currents. The mIPSCs were no longer su- 
Table 1. Effects of ISO on mIPSCs from hippocampal Swiss White, WT, and $\alpha 5^{-/-}$mice

\begin{tabular}{|c|c|c|c|c|c|c|c|}
\hline Type & Group & $n$ & Frequency $(\mathrm{Hz})$ & Amplitude (pA) & Rise (msec) & $Q$ (pA·msec) & Decay (msec) \\
\hline & Control & 5 & $3.2 \pm 1.4$ & $33.3 \pm 4.1$ & $1.9 \pm 0.2$ & $655.3 \pm 67.4$ & $17.6 \pm 1.5$ \\
\hline & ISO $25 \mu \mathrm{M}$ & 5 & $2.6 \pm 1.1$ & $31.7 \pm 1.9$ & $2.0 \pm 0.1$ & $658.6 \pm 55.2$ & $19.7 \pm 2.4$ \\
\hline \multirow[t]{3}{*}{ Swiss White } & ISO $250 \mu \mathrm{M}$ & 5 & $0.9 \pm 0.2^{*}$ & $37.2 \pm 4.2$ & $2.4 \pm 0.2^{*}$ & $1465.2 \pm 246.6^{*}$ & $57.8 \pm 11.8^{*}$ \\
\hline & Control & 5 & $2.0 \pm 1.1$ & $28.5 \pm 3.5$ & $1.9 \pm 0.3$ & $537.7 \pm 71.9$ & $16.7 \pm 2.1$ \\
\hline & $\mathrm{ISO} 25 \mu \mathrm{M}$ & 5 & $1.8 \pm 1.0$ & $27.0 \pm 2.3$ & $2.2 \pm 0.3$ & $583.7 \pm 24.7$ & $19.1 \pm 2.8$ \\
\hline \multirow[t]{3}{*}{ WT } & ISO $250 \mu \mathrm{M}$ & 5 & $1.0 \pm 0.5^{*}$ & $31.5 \pm 4.7$ & $2.7 \pm 0.3^{*}$ & $1017.4 \pm 237.4^{*}$ & $42.3 \pm 3.9^{*}$ \\
\hline & Control & 6 & $2.3 \pm 1.2$ & $30.3 \pm 2.8$ & $1.8 \pm 0.2$ & $677.9 \pm 58.3$ & $23.8 \pm 2.9$ \\
\hline & ISO $25 \mu \mathrm{M}$ & 6 & $2.3 \pm 1.1$ & $29.7 \pm 4.2$ & $1.9 \pm 0.2$ & $652.2 \pm 81.2$ & $22.6 \pm 2.7$ \\
\hline$\alpha 5^{-1-}$ & ISO $250 \mu \mathrm{M}$ & 6 & $1.3 \pm 0.5^{*}$ & $31.1 \pm 4.6$ & $2.4 \pm 0.1^{*}$ & $1130.8 \pm 180.5^{*}$ & $48.1 \pm 3.8^{*}$ \\
\hline
\end{tabular}
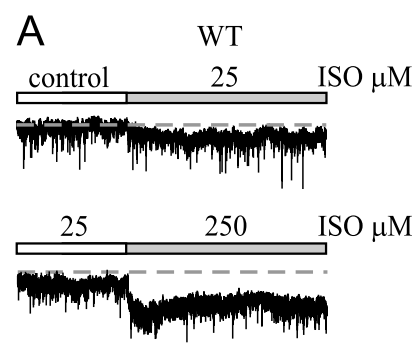



$[\mathrm{ISO} \mu \mathrm{M}]$
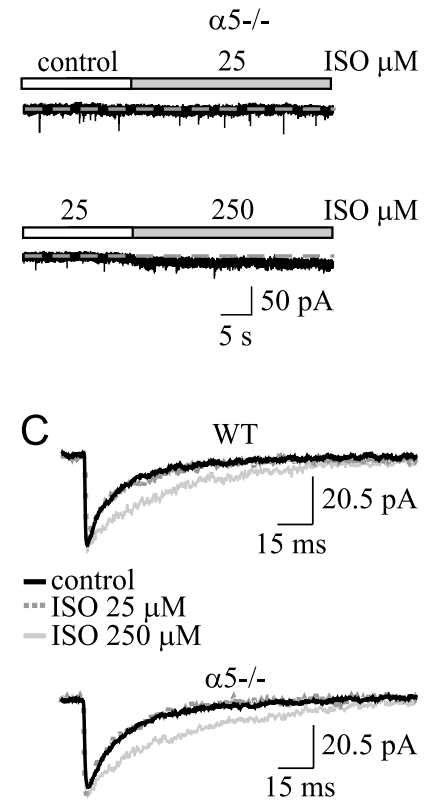

Figure 2. Effects of ISO on tonic and synaptic conductances in WT and $\alpha 5^{-/-}$neurons. $A$, The dashed gray line depicts the baseline current before drug application. The BIC-sensitive tonic current was also reduced in $\alpha 5^{-\prime-}$ compared with WT neurons ( $5.9 \pm 0.7 \mathrm{pA}, n=26 \mathrm{vs}$ $24.6 \pm 7.7 \mathrm{pA}, n=14 ; p<0.01)$. B, The bar graph illustrates the reduced effect of ISO ( 25 and $83.3 \mu \mathrm{M}$ ) on the holding current in hippocampal neurons from WT (black) and $\alpha 5^{-/-}$(gray) mice ( $\left.{ }^{*} p<0.01\right)$. In cortical neurons that express low levels of the $\alpha 5$ subunit, ISO caused similar changes in the holding current. Error bars represent SEM. C, ISO, $250 \mu \mathrm{m}$ but not $25 \mu \mathrm{m}$, prolongs mIPSCs in WT and $\alpha 5^{-/-}$neurons.

perimposed on the ISO-activated inward current, as shown in Figure $1 B$. These actions are consistent with reports that show that high concentrations of ISO reduce the vesicular release of neurotransmitter and have multiple actions on $\mathrm{GABA}_{\mathrm{A}} \mathrm{Rs}$, including direct gating and channel blockade (Banks and Pearce, 1999).

\section{The $\alpha 5$ subunit is necessary for ISO $(25 \mu \mathrm{M})$ modulation}

To determine whether $\alpha 5 \mathrm{GABA}_{\mathrm{A}}$ Rs are required for the exquisite sensitivity of the tonic conductance to ISO $(25 \mu \mathrm{M})$, currents were recorded from $\alpha 5^{-1-}$ and WT hippocampal neurons (Fig. $1 B, C)$. We also examined cortical neurons as a negative control because $\alpha 5 \mathrm{GABA}_{\mathrm{A}}$ Rs are expressed in low levels in the cortex.

ISO $(25$ and $83.3 \mu \mathrm{M})$ activated an inward current in WT but not $\alpha 5^{-1-}$ neurons $\left(25 \mu \mathrm{M}\right.$ : WT $13.6 \pm 3.8 \mathrm{pA}, n=14 \mathrm{vs} \alpha 5^{-1-}$ $0.4 \pm 2.0 \mathrm{pA}, n=25 ; 83.3 \mu \mathrm{M}$ : WT $29.2 \pm 5.5 \mathrm{pA}, n=3 \mathrm{vs} \alpha 5^{-1-}$ $0 \pm 0.3 \mathrm{pA}, n=3 ; p<0.01$ ) (Fig. $2 A, B$ ). Notably, the increase in tonic current was similar in neurons from WT and Swiss White mice. ISO $(250 \mu \mathrm{M})$ activated an inward current that was multiple-fold greater in WT compared with $\alpha 5^{-1-}$ neurons (WT $42.7 \pm 8.8 \mathrm{pA}, n=14$ vs $\left.\alpha 5^{-/-} 13.4 \pm 4.4 \mathrm{pA}, n=25 ; p<0.01\right)$ (Fig. $2 A, B)$. ISO $(250 \mu \mathrm{M})$ slowed the rise time but reduced the frequency of mIPSCs in WT and $\alpha 5^{-1-}$ neurons, as shown in neurons from Swiss White mice (Table 1, Fig. 2C). No differences were detected in the amplitude, time course, or frequency of mIPSCs for WT and $\alpha 5^{-1-}$ neurons in the absence or presence of ISO (Table 1). ISO (2500 $\mu \mathrm{M})$ abolished mIPSCs and generated a large inward current in both $\alpha 5^{-1-}$ and WT neurons (224.8 \pm $46.0 \mathrm{pA}, n=10$ vs $210.0 \pm 27.1 \mathrm{pA}, n=19$, respectively). These results suggest that the relative contribution of $\alpha 5 \mathrm{GABA}_{\mathrm{A}} \mathrm{Rs}$ to the macroscopic current activated by ISO $(2500 \mu \mathrm{M})$ was obscured by activation of other $\mathrm{GABA}_{\mathrm{A}} \mathrm{R}$ subtypes.

The application of BIC to cortical neurons from WT and $\alpha 5^{-/-}$mice failed to reveal a tonic conductance $(3.6 \pm 0.8 \mathrm{pA}$, $n=7$ vs $4.6 \pm 1.0 \mathrm{pA}, n=14$, respectively), as reported previously (Caraiscos et al., 2004). ISO (25 and $250 \mu \mathrm{M}$ ) activated a small inward current that was similar in amplitude in WT and $\alpha 5^{-1-}$ neurons (Fig. $2 B$ ). The current activated by ISO (2500 $\mu \mathrm{M})$ was not different in $\alpha 5^{-1-}$ and WT cortical neurons $(69.0 \pm$ $12.1 \mathrm{pA}, n=7$ vs $115.9 \pm 20.1 \mathrm{pA}, n=12$ ).

The $\alpha 5$ subunit confers increased ISO efficacy compared with the $\alpha 1$ subunit

To examine the specific role of $\alpha 5$ subunits in conferring sensitivity to low concentrations of ISO, currents were recorded from human $\alpha 5 \beta 3 \gamma 2 \mathrm{~L} \mathrm{GABA}_{\mathrm{A}} \mathrm{Rs}$. We also examined $\alpha 1 \beta 3 \gamma 2 \mathrm{~L}$ $\mathrm{GABA}_{\mathrm{A}}$ Rs because the $\alpha 1$ subunit is widely expressed in the brain (Fritschy and Mohler, 1995). In contrast, the $\alpha 5$ subunit is localized primarily to extrasynaptic regions of hippocampal neurons (Brunig et al., 2002). Currents were evoked by concentrations of GABA intended to mimic the saturating $(600 \mu \mathrm{M})$ and subsaturating $(3 \mu \mathrm{M})$ concentrations of neurotransmitter present in the synaptic cleft and extracellular space, respectively (Lerma et al., 1986). The same GABA concentrations were used for $\alpha 5 \beta 3 \gamma 2 \mathrm{~L}$ and $\alpha 1 \beta 3 \gamma 2 \mathrm{~L} \mathrm{GABA}_{\mathrm{A}}$ Rs because the potency of GABA is similar for both receptors (Caraiscos et al., 2004).

ISO ( 25 and $83.3 \mu \mathrm{M}$ ) potentiated the current evoked by GABA $(3 \mu \mathrm{M})$ from $\alpha 5 \beta 3 \gamma 2 \mathrm{~L} \mathrm{GABA}_{\mathrm{A}}$ Rs to 131 and $162 \%$ of control, respectively $(p<0.05)$ (Fig. $3 A, B)$. Low concentrations of ISO caused a similar potentiation of the tonic conductance in neurons from Swiss White mice and GABA-evoked current from $\alpha 5 \beta 3 \gamma 2 \mathrm{~L} \mathrm{GABA}_{\mathrm{A}}$ Rs. In contrast, the enhancement by ISO (25 $\mu \mathrm{M}$ ) was not seen for $\alpha 1 \beta 3 \gamma 2 \mathrm{~L} \mathrm{GABA}_{\mathrm{A}} \mathrm{Rs}$, as shown by the concentration-response plots (Fig. $3 A, B$ ). The maximal enhancement of both $\alpha 5 \beta 3 \gamma 2 \mathrm{~L}$ and $\alpha 1 \beta 3 \gamma 2 \mathrm{~L}$ GABA $_{\mathrm{A}}$ Rs occurred at ISO $(250 \mu \mathrm{M})$, although the increase was 1.4-fold greater for $\alpha 5 \beta 3 \gamma 2 \mathrm{~L}$ $\mathrm{GABA}_{\mathrm{A}}$ Rs. High concentrations of ISO directly gate $\mathrm{GABA}_{\mathrm{A}} \mathrm{Rs}$ when applied in the absence of GABA. To determine whether the maximum current evoked by ISO $(250 \mu \mathrm{M})$ was attributed, in 
A $\quad \alpha 5 \beta 3 \gamma 2 \mathrm{~L}$
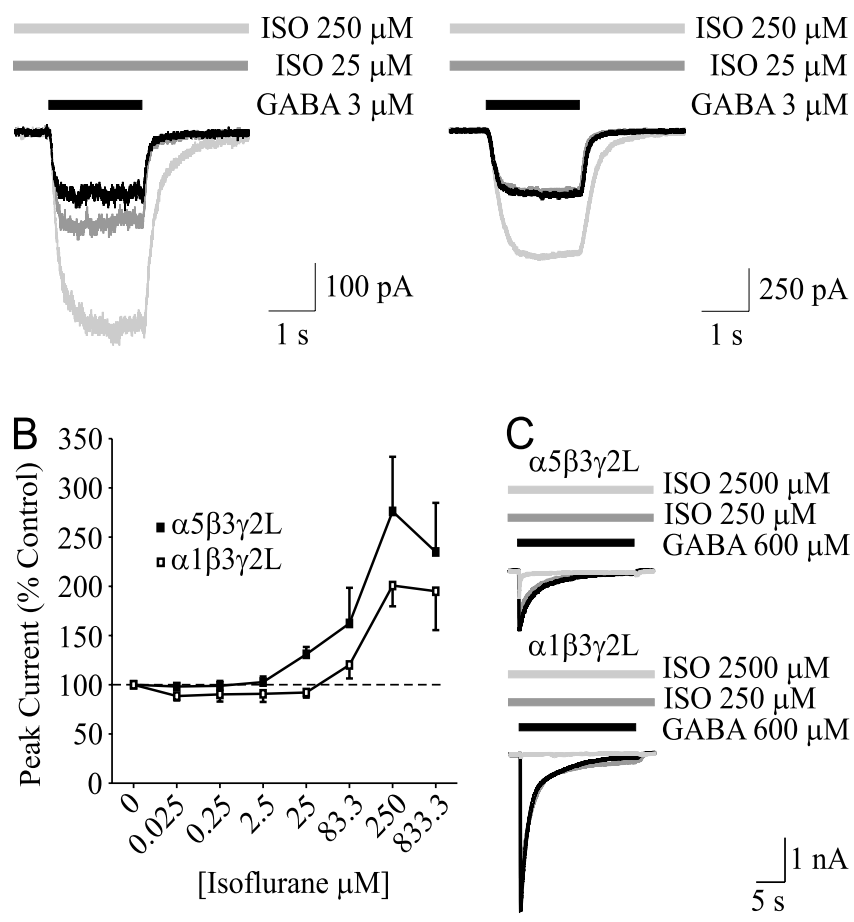

Figure 3. ISO modulates recombinant $\alpha 5 \beta 3 \gamma 2 \mathrm{~L}$ and $\alpha 1 \beta 3 \gamma 2 \mathrm{LGABA} \mathrm{A}_{\mathrm{A}} \mathrm{RS}$. A, Dual effects of ISO ( 25 and $250 \mu \mathrm{M})$ on GABA $(3 \mu \mathrm{M})$-evoked currents recorded from $\alpha 5 \beta 3 \gamma 2 \mathrm{~L}$ and $\alpha 1 \beta 3 \gamma 2 \mathrm{~L}$ $G_{A B A} R$ Ss. $B$, Concentration-response relationships for ISO enhancement of GABA-evoked current. Data points represent the mean $\pm S E M$. ISO caused a greater increase in current recorded from $\alpha 5 \mathrm{GABA}_{\mathrm{A}} \mathrm{Rs}$ compared with $\alpha 1 \mathrm{GABA}_{\mathrm{A}} \mathrm{Rs}(p<0.05)$. C, ISO $(250 \mu \mathrm{M})$ had a minimal effect on GABA $(600 \mu \mathrm{m})$-evoked current, whereas $(2500 \mu \mathrm{m})$ completely inhibited current from $\alpha 1 \beta 2 \gamma 2 \mathrm{~L}$ but not $\alpha 5 \beta 2 \gamma 2 \mathrm{~L} \mathrm{GABA}_{\mathrm{A}} \mathrm{Rs}$ (data not shown).

part, to direct gating of $\mathrm{GABA}_{\mathrm{A}} \mathrm{Rs}$, we measured currents evoked by ISO $(250 \mu \mathrm{M})$ alone. The amplitude of the ISO-evoked current was considerably less than the GABA-evoked $(3 \mu \mathrm{M})$ current from $\alpha 5 \beta 3 \gamma 2 \mathrm{~L}(17.3 \pm 5.8 \% ; n=5)$ and $\alpha 1 \beta 3 \gamma 2 \mathrm{~L} \mathrm{GABA}_{\mathrm{A}} \mathrm{Rs}$ $(12.8 \pm 2.1 \% ; n=4)$. This result indicated that direct gating failed to account for the large inward current activated by the coapplication of ISO $(\geq 250 \mu \mathrm{M})$ and GABA.

To mimic the concentration of GABA in the synaptic cleft, GABA $(600 \mu \mathrm{M})$ was applied to $\alpha 5 \beta 3 \gamma 2 \mathrm{~L}$ and $\alpha 1 \beta 3 \gamma 2 \mathrm{~L}$ $\mathrm{GABA}_{\mathrm{A}}$ Rs. ISO $(250 \mu \mathrm{M})$ modestly reduced the current from $\alpha 5 \beta 3 \gamma 2 \mathrm{~L}$ and $\alpha 1 \beta 3 \gamma 2 \mathrm{~L}$ to $84.0 \pm 3.5 \%(n=6)$ and $80.4 \pm 5.4 \%$ $(n=7)$ of control, respectively (Fig. $3 C)$. Consistent with complete inhibition of the mIPSCs, ISO $(2500 \mu \mathrm{M})$ blocked the GABA-evoked current from $\alpha 1 \beta 3 \gamma 2 \mathrm{~L} \mathrm{GABA}_{\mathrm{A}}$ Rs $(1.0 \pm 1.2 \%$ of control; $n=5 ; p<0.05)$. In contrast, the current from $\alpha 5 \beta 3 \gamma 2 \mathrm{~L}$ $\mathrm{GABA}_{\mathrm{A}} \mathrm{Rs}$ was reduced to $38.5 \pm 11.5 \%$ of control $(n=5 ; p<$ 0.05) (Fig. 3C).

\section{Discussion}

Many neurodepressive drugs are thought to reduce neuronal excitability by increasing inhibitory synaptic transmission. However, a picture is emerging of a family of tonic $\mathrm{GABA}_{\mathrm{A}}$ Rs that "fine tune" neuronal excitability by regulating a conductance leak (Semyanov et al., 2004). Here, we report that low concentrations of the volatile anesthetic ISO $(25 \mu \mathrm{M})$ selectively enhance the tonic but not synaptic current in hippocampal pyramidal neurons. The $\alpha 5$ subunit is necessary for enhancement by ISO (25 and $83.3 \mu \mathrm{M}$ ) because potentiation is absent in $\alpha 5^{-1-}$ neurons. Furthermore, studies using recombinant human $\alpha 5 \beta 3 \gamma 2 \mathrm{~L}$ and $\alpha 1 \beta 3 \gamma 2 \mathrm{~L} \mathrm{GABA}_{\mathrm{A}}$ Rs show that the $\alpha 5$ subunit confers sensitivity to these low concentrations of ISO.

Our results are consistent with previous reports that show relatively high concentrations of volatile anesthetics are required to enhance inhibitory synaptic transmission in hippocampal neurons. Other investigators report that the lowest concentration of ISO that prolongs inhibitory synaptic currents in cultured rat hippocampal neurons and CA1 pyramidal neurons in hippocampal slices is $\sim 100 \mu \mathrm{M}$ with a half-maximal effective concentration of $320 \mu \mathrm{M}$ (Jones and Harrison, 1993; Banks and Pearce, 1999). The 2.5-fold enhancement of spontaneous IPSCs in CA1 pyramidal neurons by ISO $(300 \mu \mathrm{M})$ (Banks and Pearce, 1999) is similar to the prolongation of mIPSCS by ISO $(250 \mu \mathrm{M})$ we observed. These results indicate that a considerably greater ISO concentration is required to potentiate the synaptic compared with tonic current.

The $\alpha$ subunit isoform influences the sensitivity of $\mathrm{GABA}_{\mathrm{A}} \mathrm{Rs}$ to halogenated ethers, including ISO (Jenkins et al., 2001). Positive modulation of $\mathrm{GABA}_{\mathrm{A}} \mathrm{R}$ activity has been attributed to interactions of anesthetics with specific amino acid residues in transmembrane domains 2 and 3 of the $\alpha$ subunit (Mihic et al., 1997; Krasowski et al., 1998; Nishikawa et al., 2002). Mutations of Ser270 or Ala-291 in the $\alpha$ subunit result in recombinant $\mathrm{GABA}_{\mathrm{A}} \mathrm{Rs}$ that are insensitive to clinically relevant concentrations of ISO (Krasowski et al., 1998). Amino acid residues that contribute to the putative anesthetic binding cavity are conserved across all $\alpha$ isoforms, suggesting that the differential effects of ISO on $\alpha 5 \mathrm{GABA}_{\mathrm{A}}$ Rs compared with $\alpha 1 \mathrm{GABA}_{\mathrm{A}}$ Rs result from interactions with yet unidentified components of the binding cavity or transduction pathways. The structural basis for the enhanced sensitivity of $\alpha 5 \mathrm{GABA}_{\mathrm{A}} \mathrm{Rs}$ to ISO warrants additional investigation.

Our results support a growing body of literature that shows structurally diverse GABAergic drugs preferentially enhance a tonic conductance. We previously showed that the intravenous anesthetic propofol caused a greater increase in the tonic compared with synaptic conductance (Bai et al., 2001). This increase in tonic conductance by propofol reduces neuronal excitability (Bieda and MacIver, 2004). Until we determined that $\alpha 5 \mathrm{GABA}_{\mathrm{A}}$ Rs generated the tonic current (Caraiscos et al., 2004), it was impossible to discern whether the pharmacology of the tonic conductance resulted from subunit composition and/or conditions of receptor activation. The efficacy of ISO is greater for $\alpha 5 \mathrm{GABA}_{\mathrm{A}} \mathrm{Rs}$ compared with the $\alpha 1 \mathrm{GABA} \mathrm{A}_{\mathrm{A}} \mathrm{R}$, and the increase in $\mathrm{GABA}_{\mathrm{A}} \mathrm{R}$ activity by anesthetics is greatest when receptors are activated by low GABA concentrations (Harris et al., 1995). Thus, both subunit composition and low GABA occupancy contribute to the preferential enhancement of the tonic conductance.

Low concentrations of ISO suppress learning in humans and animals. The steady-state concentration of ISO that impairs memory in rats is estimated to be $\sim 25 \%$ of MAC (Dutton et al., 2001). The neural correlates underlying complex behavioral phenomena including learning and memory remain unknown. $\alpha 5 \mathrm{GABA}_{\mathrm{A}}$ Rs may play an important role in cognitive function because mice lacking the $\alpha 5$ subunit display enhanced learning and memory for hippocampal-dependent behaviors (Collinson et al., 2002; Crestani et al., 2002). In light of our findings that $\alpha 5^{-/-}$neurons appear to be insensitive to low concentrations of ISO ( $83.3 \mu \mathrm{M} ; 33 \% \mathrm{MAC})$, we speculate that modulation of $\alpha 5 \mathrm{GABA}_{\mathrm{A}} \mathrm{Rs}$ in hippocampal neurons contributes to the amnestic properties of volatile anesthetics. 


\section{References}

Bai D, Zhu G, Pennefather P, Jackson MF, MacDonald JF, Orser BA (2001) Distinct functional and pharmacological properties of tonic and quantal inhibitory postsynaptic currents mediated by $\gamma$-aminobutyric acid receptors in hippocampal neurons. Mol Pharmacol 59:814-824.

Banks MI, Pearce RA (1999) Dual actions of volatile anesthetics on GABA(A) IPSCs: dissociation of blocking and prolonging effects. Anesthesiology 90:120-134.

Belelli I, Pistis I, Peters JA, Lambert JJ (1999) General anaesthetic action at transmitter-gated inhibitory amino acid receptors. Trends Pharmacol Sci 20:496-502.

Bieda MC, MacIver MB (2004) Major role for tonic $\mathrm{GABA}_{\mathrm{A}}$ conductances in anesthetic suppression of intrinsic neuronal excitability. J Neurophysiol 92:1658-1667.

Brunig I, Scotti E, Sidler C, Fritschy JM (2002) Intact sorting, targeting, and clustering of gamma-aminobutyric acid $_{\mathrm{A}}$ receptor subtypes in hippocampal neurons in vitro. J Comp Neurol 443:43-55.

Campagna JA, Miller KW, Forman SA (2003) Mechanisms of actions of inhaled anesthetics. N Engl J Med 348:2110-2124.

Caraiscos VB, Elliott EM, You T, Cheng VY, Belelli D, Newell JG, Jackson MF, Lambert JJ, Rosahl TW, Wafford KA, MacDonald JF, Orser BA (2004) Tonic inhibition in mouse hippocampal CA1 pyramidal neurons is mediated by $\alpha 5$ subunit-containing $\gamma$-aminobutyric acid type A receptors. Proc Natl Acad Sci USA 101:3662-3667.

Collinson N, Kuenzi FM, Jarolimek W, Maubach KA, Cothliff R, Sur C, Smith A, Out FM, Howell O, Atack JR, McKernan RM, Seabrook GR, Dawson GR, Whiting PJ, Rosahl TW (2002) Enhanced learning and memory and altered GABAergic synaptic transmission in mice lacking the $\alpha 5$ subunit of the $\mathrm{GABA}_{\mathrm{A}}$ receptor. J Neurosci 22:5572-5580.

Cook TL, Smith M, Winter PM, Starkweather JA, Eger 3rd EI (1978) Effect of subanesthetic concentrations of enflurane and halothane on human behavior. Anesth Analg 57:434-440.

Crestani F, Keist R, Fritschy JM, Benke D, Vogt K, Prut L, Blüthmann H, Mohler H, Rudolph U (2002) Trace fear conditioning involves hippocampal $\alpha 5 \mathrm{GABA}_{\mathrm{A}}$ receptors. Proc Natl Acad Sci USA 99:8980-8985.

Dutton RC, Maurer AJ, Sonner JM, Fanselow MS, Laster MJ, Eger EI (2001) The concentration of isoflurane required to suppress learning depends on the type of learning. Anesthesiology 94:514-519.

Dwyer R, Bennett HL, Eger EI, Heilbron D (1992) Effects of isoflurane and nitrous oxide in subanesthetic concentrations on memory and responsiveness in volunteers. Anesthesiology 77:888-898.

Eger EI, Saidman LJ, Brandstater B (1965) Minimum alveolar anesthetic concentration: a standard of anesthetic potency. Anesthesiology 26:756-763.

Franks NP, Lieb WR (1993) Selective actions of volatile general anaesthetics at molecular and cellular levels. Br J Anaesth 71:65-76.

Franks NP, Lieb WR (1998) Which molecular targets are most relevant to general anaesthesia? Toxicol Lett 100-101:1-8.

Fritschy JM, Mohler H (1995) GABA $_{\mathrm{A}}$-receptor heterogeneity in the adult rat brain: differential regional and cellular distribution of seven major subunits. J Comp Neurol 359:154-194.

Gillespie NA (1943) The signs of anesthesia. Anesth Analg 22:275-282.

Harris RA, Mihic SJ, Dildy-Mayfield JE, Machu TK (1995) Actions of anesthetics on ligand-gated ion channels: role of receptor subunit composition. FASEB J 9:1454-1462.

Jenkins A, Greenblatt EP, Faulkner HJ, Bertaccini E, Light A, Lin A, Andreasen A, Viner A, Trudell JR, Harrison NL (2001) Evidence for a com- mon binding cavity for three general anesthetics within the $\mathrm{GABA}_{\mathrm{A}}$ receptor. J Neurosci 21:1-4.

Jones MV, Harrison NL (1993) Effects of volatile anesthetics on the kinetics of inhibitory postsynaptic currents in cultured rat hippocampal neurons. J Neurophysiol 70:1339-1349.

Joo DT, Gong D, Sonner JM, Jia Z, MacDonald JF, Eger EI, Orser BA (2001) Blockade of AMPA receptors and volatile anesthetics: reduced anesthetic requirements in GluR2 null mutant mice for loss of the righting reflex and antinociception but not minimum alveolar concentration. Anesthesiology $94: 478-488$.

Kandel L, Chortkoff BS, Sonner J, Laster MJ, Eger EI (1996) Nonanesthetics can suppress learning. Anesth Analg 82:321-326.

Korpi ER, Gründer G, Luddens H (2002) Drug interactions at GABA $\mathrm{A}$ receptors. Prog Neurobiol 67:113-159.

Krasowski MD, Koltchine VV, Rick CE, Ye Q, Finn SE, Harrison NL (1998) Propofol and other intravenous anesthetics have sites of action on the $\gamma$-aminobutyric acid type A receptor distinct from that for isoflurane. Mol Pharmacol 53:530-538.

Lerma J, Herranz AS, Herreras O, Abraira V, Martin DR (1986) In vivo determination of extracellular concentration of amino acids in the rat hippocampus. A method based on brain dialysis and computerized analysis. Brain Res 384:145-155.

MacDonald JF, Mody I, Salter MW, Pennefather P, Schneiderman JH (1989) The regulation of NMDA receptors in the central nervous system. Prog Neuropsychopharmacol Biol Psychiatry 13:481-488.

McKernan RM, Whiting PJ (1996) Which $\mathrm{GABA}_{\mathrm{A}}$-receptor subtypes really occur in the brain? Trends Neurosci 19:139-143.

Mihic SJ, McQuilkin SJ, Eger EI, Ionescu P, Harris RA (1994) Potentiation of gamma-aminobutyric acid type A receptor-mediated chloride currents by novel halogenated compounds correlates with their abilities to induce general anesthesia. Mol Pharmacol 46:851-857.

Mihic SJ, Ye Q, Wick MJ, Koltchine VV, Krasowski MD, Finn SE, Mascia MP, Valenzuela CF, Hanson KK, Greenblatt EP, Harris RA, Harrison NL (1997) Sites of alcohol and volatile anaesthetic action on $\mathrm{GABA}_{\mathrm{A}}$ and glycine receptors. Nature 389:385-389.

Nishikawa K, Jenkins A, Paraskevakis I, Harrison NL (2002) Volatile anesthetic actions on the $\mathrm{GABA}_{\mathrm{A}}$ receptors: contrasting effects of $\alpha 1 \mathrm{~S} 270$ and $\beta 2$ N265 point mutations. Neuropharmacology 42:337-345.

Pain L, Angst MJ, LeGourrier L, Oberling P (2002) Effect of a nonsedative dose of propofol on memory for aversively loaded information in rats. Anesthesiology 97:447-453.

Semyanov A, Walker MC, Kullmann DM, Silver RA (2004) Tonically active $\mathrm{GABA}_{\mathrm{A}}$ receptors: modulating gain and maintaining the tone. Trends Neurosci 27:262-269.

Veselis RA, Reinsel RA, Feshchenko VA (2001) Drug-induced amnesia is a separate phenomenon from sedation: electrophysiologic evidence. Anesthesiology 95:896-907.

Wall MJ, Usowicz MM (1997) Development of action potential-dependent and independent spontaneous $\mathrm{GABA}_{\mathrm{A}}$ receptor-mediated currents in granule cells of postnatal rat cerebellum. Eur J Neurosci 9:533-548.

Wu Y, Wang W, Richerson GB (2003) Vigabatrin induces tonic inhibition via GABA transporter reversal without increasing vesicular GABA release. J Neurophysiol 89:2021-2034.

Yeung JY, Canning KJ, Zhu G, Pennefather P, MacDonald JF, Orser BA (2003) Tonically activated $\mathrm{GABA}_{\mathrm{A}}$ receptors in hippocampal neurons are high-affinity, low-conductance sensors for extracellular GABA. Mol Pharmacol 63:2-8. 